\title{
First record of African brown snapper Lutjanus dentatus in the Canary Islands (north-eastern Atlantic Ocean)
}

\author{
ANTONIO M. GARCÍA-MEDEROS ${ }^{1}$ AND VÍCTOR M. TUSET ${ }^{2}$ \\ ${ }^{1}$ Servicio de Inspección Pesquera, Viceconsejería de Pesca y Aguas, Consejería de Agricultura, Ganadería, Pesca y Aguas, Gobierno \\ de Canarias, Avenida Alcalde Ramírez Bethencourt 22, 35071, Las Palmas de Gran Canaria, Islas Canarias, Spain, ${ }^{2}$ Institute of \\ Marine Science (ICM-CSIC), Passeig Marítim 37-49, 08003, Barcelona, Spain
}

The African brown snapper Lutjanus dentatus is a fish native of the West African coastal zone of the Atlantic Ocean. Here we document the first recorded capture of this species in the Canary Islands, an archipelago close to Africa, in August 2013.

Keywords: Lutjanus dentatus, fish, first record, range expansion, Canary Islands

Submitted 4 March 2014; accepted 5 June 2014

\section{INTRDDUCTIDN}

The snappers (Lutjanidae) are circumtropical fish, comprising 17 genera and 110 species (Allen, 1985; Cervigón, 1993; Froese \& Pauly, 2013). The Indo-Pacific region is considered to be where snappers appeared, in the light of their high variability of genera, diversity of species and endemism (Druzhinin, 1970), although it is not known whether all Lutjanidae arose from a single Indo-Pacific lineage (Miller \& Crib, 2007). Snappers play an important role in the ecology of reefs, mangrove swamps and seagrasses (e.g. Aiken, 1993; Appeldoorn \& Meyers, 1993; Baisre, 2000; Claro et al., 2001; Teixeira et al., 2010); moreover, they are very important commercial fish in tropical and subtropical seas (Randall, 1995; Valinassab et al., 2006; Grandcourt et al., 2008). Some snappers have been introduced to new regions to enhance sport fisheries (Baltz, 1991), and in addition, there are reported cases of translocation of snappers, for example, from the Red Sea into the Mediterranean Sea (Vacchi et al., 2010). Since snappers are opportunistic feeders and have an aggressive feeding behaviour (e.g. Rooker, 1995; Grandcourt et al., 2008), they may oust and be a threat to native populations of fish and even oust them (Friedlander et al., 2002).

Off the African coasts, from Senegal to Angola (central eastern Atlantic), there occur five species of the genus Lutjanus (Allen, 1985): L. dentatus (Duméril, 1858); L. agennes (Bleeker, 1863); L. endecacanthus (Bleeker, 1863); L. fulgens (Valenciennes, 1830); and L. goreensis (Valenciennes, 1830). Of these, L. goreensis have been reported around the Canary Islands (González \& Santana, 1986; Brito et al., 2005), an archipelago close to the African coast.

\section{MATERIALS AND METHDDS}

On 15 August 2013, one specimen of African brown snapper Lutjanus dentatus (Figure 1) was caught with a bottom trap at $100 \mathrm{~m}$ in a rocky bottom off the Agaete coast $\left(28^{\circ} 05.33^{\prime} \mathrm{N}\right.$ $15^{\circ} 49.56^{\prime} \mathrm{W}$ ) (Gran Canaria Island, Canary Islands, northeastern Atlantic Ocean). The individual was photographed and then kept frozen within a labelled plastic bag. Several days later, it was taxonomically identified by using the Food and Agriculture Organization of the United Nations key for the Eastern Central Atlantic (Allen, 1985). Furthermore, a morphometric and meristic analysis was performed in accordance with the standard procedures for fish. Subsequently, the specimen was sent to and deposited at the Museum of Nature and Man at Tenerife (Tenerife, Canary Islands) with the code TFMCBM-VP/1944. This occurrence constitutes the first record of this species around the Canary Islands.

\section{RESULTS AND DISCUSSIDN}

The specimen measured $107.5 \mathrm{~cm}$ in total length (TL) and $91 \mathrm{~cm}$ in standard length (SL); it had a total weight (TW) of $23 \mathrm{~kg}$. Thus, L. dentatus can be considered a large-sized predator, which can attain a maximum TL around $150 \mathrm{~cm}$ (Allen,

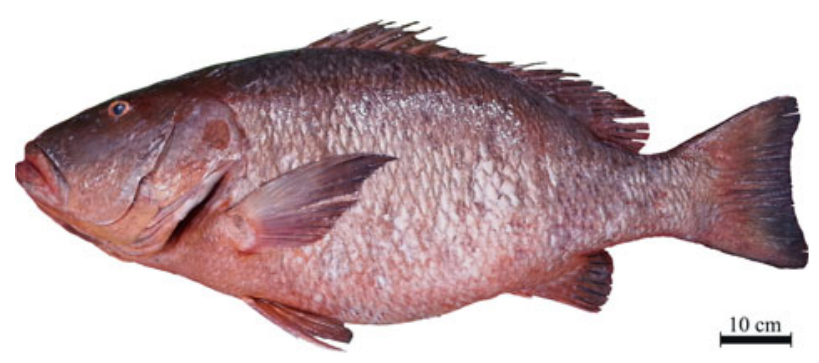

Fig. 1. Non-native specimen, Lutjanus dentatus, from the Gulf of Guinea collected in the Canary Islands.
Corresponding author:

V.M. Tuset

Email: vtuset@icm.csic.es 
1986). The presence of large-sized demersal fish, such as Epinephelus itajara (Lichtenstein, 1822), Argyrosomus regius (Asso, 1801) or Cephalopholis taeniops (Valenciennes, 1828) off the West African coast has been described as occasional in the Canary Islands (Brito et al., 2005, 2011). However, these predators may have significant repercussions in ecosystems where they can establish themselves, because they often feed at higher trophic levels (Petchey et al., 2008) and thereby strongly affect the food webs (Côté et al., 2013).

In the decade of the 1980s, the presence among the Canary Islands of fish such as L. goorensis from the African coast was associated with mass movements of water (González \& Santana, 1986). Brito et al. (2005) concluded that the increase in the population of tropical littoral fish fauna in the Canarian archipelago was mainly due to ocean warming, and more recently numerous studies have revealed that latitudinal shifts in certain assemblages can be associated with warming waters (e.g. Perry et al., 2005; Machado \& Barreiros, 2006; Abecasis et al., 2008; Azurro et al., 2011: GonzálezWangüemert \& Borrero-Pérez, 2012). However, Brito et al. (2011), in the light of repeated observations of specimens of C. taeniops inside oil platforms, emphasized that maritime transport between the African coast and the Canary Islands might serve as a channel for carrying new species, and especially for large-sized carnivorous fish.

The African brown snapper was distinguished from the other snappers inhabiting the West African coast by its tooth pattern and meristic data (Allen, 1985); the vomerine teeth did not present extensions, as occurs in L. goreensis and L. fulgens. In addition, the meristic counts were: dorsal fin with 10 spines and 14 rays; anal fin with 3 spines and 8 rays; and pectoral fin with 17 rays. Eight well-formed gill rakers (excluding rudimentary ones) on the anterior gill arch, 1 on the upper limb and 7 on the lower limb were also noted. Finally, a total of 5 longitudinal scale rows above the lateral line and 10 scale rows on the cheek were counted. Lutjanus dentatus differs from $L$. agennes in the higher number (9 or 10) of scale rows on the cheek, and from L. endecanthus in the smaller number (4 or 5 ) of longitudinal scale rows above the lateral line, and in having a more pointed snout.

The body proportions of our present specimen are as follows: SL is $85 \%$ of TL; body depth is $37 \%$ of SL; pectoral ray length is $24 \%$ of SL; pelvic ray length is $17 \%$ of SL; head length (HL) is $32 \%$ of SL; head depth is $27 \%$ of SL; eye diameter is $10 \%$ of $\mathrm{HL}$; interorbital width is $24 \%$ of $\mathrm{HL}$; distance from upper lip to eye is $35 \%$ of $\mathrm{HL}$; preorbital distance is $43 \%$ of $\mathrm{HL}$; and pre-opercular distance is $40 \%$ of $\mathrm{HL}$. In addition, the specimen presented a brownish colour dorsally, and ranged from brownish to pink on the lateral and ventral surfaces; the ventral zone of the head acquired an orange colour, and the posterior parts of the fins were dark. A recent study (Miller \& Cribb, 2007) demonstrated that the morphology and external coloration of snappers were congruent with their phylogenetic evolution, and recognized several clades: 'blue-lined'; 'black spot' complex; 'yellow-lined'; and 'redlined'. In the light of all of its morphological and colour traits, it is very likely that $L$. dentatus is close to the 'redlined' clade, characterized in that the adults live alone, exhibit territorial behaviour and inhabit deeper or dimly illuminated waters (e.g. Allen, 1985; Appeldoorn \& Meyers, 1993; Baisre, 2000; Teixeira et al., 2010). This also seems to be consistent with the depth $(100 \mathrm{~m})$ at which the present specimen was captured.

\section{ACKNDWLEDGEMENTS}

We thank Mrs Juana Ojeda García, secretary of Agaete Fishing Port, for providing the specimen. We also thank Dr Gerald R. Allen for his help in its identification. Thanks are expressed to the referees for comments and advice on the improvement of the manuscript. We also acknowledge Ron Price for her assistance in the language editing of this manuscript.

\section{FINANCIAL SUPPDRT}

This research received no specific grant from any funding agency, commercial or not-for-profit sectors.

\section{REFERENCES}

Abecasis D., Bentes L., Ribeiro J., Machado D., Oliveira F., Veiga P., Gonçalves J.M.S. and Erzini K. (2008) First record of the Mediterranean parrotfish, Sparisoma cretense in Ria Formosa (south Portugal). Marine Biodiversity Records 1, e27. doi: http://dx.doi.org/

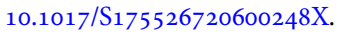

Aiken K.A. (1993) Jamaica. In Marine fishery resources of the Lesser Antilles, Puerto Rico and Hispaniola. FAO Fisheries Technical Paper $326,1160-1180$.

Allen G.R. (1985) FAO species catalogue. Volume 6. Snappers of the world. An annotated and illustrated catalogue of lutjanid species known to date. FAO Fisheries Synopsis 125, 1-208.

Allen G.R. (1986) Lutjanidae. In Daget J., Gosse J.P. and Thys van den Audenaerde D.F.E. (eds) Check-list of the freshwater fishes of Africa (CLOFFA), Volume 2. Paris and Brussells and Tervuren: MRAC and ORSTOM, pp. 323-324.

Appeldoorn R.S. and Meyers S. (1993) Puerto Rico and Hispaniola. FAO Fisheries Technical Paper 32, 99-159.

Azurro E., Moschella P. and Maynou F. (2011) Tracking signals of change in Mediterranean fish diversity based on local ecological knowledge. PLOSONE 6, e24885. doi:10.1371/journal.pone.0024885.

Baisre J.A. (2000) Chronicle of Cuban marine fisheries (1935-1995). Trend analysis and fisheries potential. FAO Fisheries Technical Paper $394,1-26$.

Baltz D.M. (1991) Introduced fishes in marine systems and inland seas. Biological Conservation 56, 151-177.

Brito A., Falcón J.M. and Herrera R. (2005) Sobre la tropicalización reciente de la ictiofauna litoral de las islas Canarias y su relación con cambios ambientales y actividades antrópicas. Vieraera 33, 515-525.

Brito A., Clemente S. and Herrera R. (2011) On the occurrence of the African hind, Cephalopholis taeniops, in the Canary Islands (eastern subtropical Atlantic): introduction of large-sized demersal littoral fishes in ballast water of oil platforms? Biological Invasions 13, 2185-2189.

Cervigón F. (1993) Los peces marinos de Venezuela. Volume 2. Caracas, Venezuela: Fundación Cientifica Los Roques, 954 pp.

Claro R., Lindeman K.C. and Parenti L.R. (2001) Ecology of the marine fishes of Cuba. Washington, DC: Smithsonian Institution Press, $253 \mathrm{pp}$. 
Côté I.M., Green S.J. and Hixon M.A. (2013) Predatory fish invaders: insights from Indo-Pacific lionfish in the western Atlantic and Caribbean. Biological Conservation 164, 50-61.

Druzhinin A.D. (1970) The range and biology of snappers (Family Lutjanidae). Journal of Ichthyology 10, 717-736.

Friedlander A.M., Parrish J.D. and DeFelice R.C. (2002) Ecology of the introduced snapper Lutjanus kasmira (Forsskal) in the reef fish assemblage of a Hawaiian bay. Journal of Fish Biology 6o, 28-48.

Froese R. and Pauly D. (2013) FishBase. World Wide Web electronic publication. Available at: www.fishbase.org (accessed 13 May 2014).

González J.A. and Santana J.I. (1986) Sobre la presencia de Lutjanus goreensis (Valenciennes, 1830) (Osteichthyes: Lutjanidae) en aguas de Canarias. Vieraea 16, 282-286.

González-Wangüemert M. and Borrero-Pérez G. (2012) A new record of Holothuria arguinensis colonizing the Mediterranean Sea. Marine Biodiversity Records 5, e105. doi: http://dx.doi.org/10.1017/ S1755267212000887.

Grandcourt E.M., Hecht T., Booth A.J. and Robinson J. (2008) Retrospective stock assessment of the Emperor red snapper (Lutjanus sebae) on the Seychelles Bank between 1977 and 2006. ICES Journal of Marine Science 65, 889-898.

Machado LF. and Barreiros J.P. (2006) First records of Seriola fasciata (Carangidae) in the Azores. A northernmost occurrence in the NE Atlantic. Cybium 30, 77-78.

Miller T.L. and Cribb T.H. (2007) Phylogenetic relationships of some common Indo-Pacific snappers (Perciformes: Lutjanidae) based on mitochondrial DNA sequences with comments on the taxonomic position of the Caesioninae. Molecular Phylogenetics and Evolution 44, $450-460$.
Perry A.L., Low P.J., Ellis J.R. and Reynolds J.D. (2005) Climate change and distribution shifts in marine fishes. Science 308, 1912-1915.

Petchey O.L., Beckerman A.P., Riede J.O. and Warren P.H. (2008) Size, foraging, and food web structure. Proceedings of the National Academy of Sciences of the United States of America 105, 4191-4196.

Randall J.E. (1995) Coastal fishes of Oman. Honolulu: University of Hawaii Press, 439 pp.

Rooker J. (1995) Feeding ecology of the schoolmaster snapper, Lutjanus apodus (Walbaum), from southwestern Puerto Rico. Bulletin of Marine Science 56, 881-894.

Teixeira S.F., Yalan F.D. and Ferreira B.P. (2010) Reproduction of the fish Lutjanus analis (mutton snapper; Perciformes: Lutjanidae) from Northeastern Brazil. Revista de Biología Tropical 58, 791-80o.

Vacchi M., Psomadakis P.N., Repetto N. and Würtz M. (2010) First record of the dog snapper Lutjanus jocu in the Mediterranean Sea. Journal of Fish Biology 76, 723-728.

and

Valinassab T., Daryanabard R., Dehghani R. and Pierce G.J. (2006) Abundance of demersal fish resources in the Persian Gulf and Oman Sea. Journal of the Marine Biological Association of the United Kingdom 86, 1455-1462.

\section{Correspondence should be addressed to:}

V.M. Tuset

Department of Marine Renewable Resources

Institute of Marine Science (ICM-CSIC)

Barcelona, Spain

email: vtuset@icm.csic.es 